\section{Managing Plant-Parasitic Nematodes in Established Red Raspberry Fields}

\author{
Thomas W. Walters ${ }^{1,6}$, John N. Pinkerton², Ekaterini Riga ${ }^{3}$, \\ Inga A. Zasada ${ }^{2}$, Michael Particka $^{1}$, Harvey A. Yoshida ${ }^{4}$, \\ and Chris Ishida ${ }^{5}$
}

Additional Index words. Rubus idaeus, root lesion nematode, Pratylenchus penetrans, dagger nematode, Xiphinema bakeri

SUMmARY. The efficacy and phytotoxicity of postplant treatments to control root lesion nematodes [RLN (Pratylenchus penetrans)] and dagger nematodes [DN (Xiphinema bakeri)] in red raspberry (Rubus idaeus) were evaluated in four field studies, each conducted over 1 to 3 years. Spring spray applications of oxamyl or fosthiazate reduced RLN and DN population densities for up to 2 years, but fall oxamyl sprays and spring drip-applied oxamyl applications were not effective. Oxamyl application rate determined the duration of nematode suppression. Two spring applications of oxamyl at $2 \mathrm{lb} /$ acre provided more than 2 years of suppression, while two spring applications of $0.8 \mathrm{lb} /$ acre suppressed nematodes for only 1 year. Spring oxamyl applications reduced 'Nootka' fruit yield for one season, but did not affect 'Willamette' yield. Fall spray-applied fenamiphos, fall and spring spray-applied DiTera (a fermentation product of the fungus Myrothecium verrucaria), fall drip-applied 1,3-dichloropropene, and spring shallow-incorporated abyssinian mustard (Brassica carinata) seed meal suppressed RLN briefly (less than 6 months) or not at all.

$\mathrm{P}$ lant-parasitic nematodes are major pests of red raspberry, reducing yield and cane growth, and leading to economic losses in many production regions (Belair, 1991; McElroy, 1991; Szczygiel and Rebandel, 1988; Trudgill, 1986). Three plant-parasitic nematode species are of importance in red raspberry production in the Pacific northwestern United States: root lesion nematodes and the dagger nematode species Xiphinema bakeri and X. americanum (McElroy, 1992). RLN is a migratory endoparasite that moves between soil and roots, but feeds on and migrates in root cortical cells. These activities kill tissues in the root cortex, which appear as necrotic lesions or spots on the

This research was funded by the Northwest Center for Small Fruits Research, the Washington Red Raspberry Commission, the Washington State Commission on Pesticide Registration, and by research gifts from DuPont, Dow AgroSciences, and Valent BioSciences.

We thank Darryl Ehlers for hosting these trials and for his valuable cooperation, and we thank Norm McKinley for his valuable input.

${ }^{1}$ Washington State University-Mount Vernon NWREC, Mt. Vernon, WA 98273

${ }^{2}$ U.S. Department of Agriculture-Agricultural Research Service HCRL, Corvallis, OR 97330

${ }^{3}$ Washington State University-Prosser IAREC, Prosser, WA 99350

${ }^{4}$ Dow AgroSciences, Richland, WA 99352

${ }^{5}$ Valent BioSciences, Vancouver, WA 98687

${ }^{6}$ Corresponding author. E-mail: twwalters@wsu.edu. roots. Feeder roots are destroyed over time, leaving only woody roots. Infested plants often decline over a 3- to 4-year period, produce fewer canes and fruit, and are more susceptible to winter injury. In addition, RLN can make roots more susceptible to other soil-borne plant pathogens (Vrain and Copeman, 1987; Vrain and Pepin, 1989). These interactions are exacerbated when the plants are under stress (McElroy, 1991).

In contrast, $\mathrm{DN}$ species are ectoparasites; they do not enter the root, but feed on the growing root tips (McElroy, 1991). X. bakeri feeding causes direct damage to roots, observed as diagnostic "fishhook" swelling of the root tips (McElroy, 1972, 1991). Continued feeding stunts root and cane growth and reduces fruit yields within several years. Planting raspberry into soil infested with high population densities of RLN or $X$. bakeri may result in reduced establishment and high mortality of young plants (McElroy, 1972, 1991, 1992). $X$. americanum does not cause direct damage to raspberry, but is a vector of tomato ringspot virus (ToRSV) (McElroy, 1991, 1992). ToRSV infected plants are stunted, produce crumbly, nonmarketable fruit, and may die within 3 to 4 years after being infected. Even low population densities of $X$. americanum are problematic because they can transmit ToRSV.

Before planting red raspberries, the soil should be sampled for plantparasitic nematodes and fumigated when threshold populations of RLN or DN are present (McElroy, 1991, 1992). Even with adequate soil fumigation, nematode population densities can build up from below detectable levels to damaging levels within 6 to 8 years. In established plantings infested with RLN, fall fenamiphos applications were recommended for reducing nematode population densities and increasing plant growth and yield (McElroy, 1991). However, fenamiphos was not effective at reducing DN population densities (McElroy, 1992). Fenamiphos has been removed from the market and currently there are no post-plant nematicides registered for use on raspberry in the United States. In addition, the future use of preplant soil fumigants in raspberry fields may become more restricted because environmental, worker, and public safety concerns have led to significant reregistration requirements for soil fumigants (U.S. Environmental Protection Agency, 2008). There is a need for new preplant and postplant strategies for managing plant-parasitic nematodes in raspberry. The objective of this research was to identify syntheticand biologically based nematicides for

\begin{tabular}{llll}
\hline $\begin{array}{l}\text { Units } \\
\text { To convert U.S. to SI, } \\
\text { multiply by }\end{array}$ & U.S. unit & SI unit & $\begin{array}{l}\text { To convert SI to U.S., } \\
\text { multiply by }\end{array}$ \\
\hline 0.3048 & $\mathrm{ft}$ & $\mathrm{m}$ & 3.2808 \\
3.7854 & $\mathrm{gal}$ & $\mathrm{L}$ & 0.2642 \\
9.3540 & gal/acre & $\mathrm{L} \cdot \mathrm{ha}^{-1}$ & 0.1069 \\
2.54 & inch $(\mathrm{es})$ & $\mathrm{cm}$ & 0.3937 \\
25.4 & inch $(\mathrm{es})$ & $\mathrm{mm}$ & 0.0394 \\
1.1209 & lb/acre & $\mathrm{kg} \cdot \mathrm{ha}^{-1}$ & 0.8922 \\
28.3495 & $\mathrm{oz}$ & $\mathrm{g}$ & 0.0353 \\
6.8948 & $\mathrm{psi}$ & $\mathrm{kPa}$ & 0.1450 \\
2.2417 & ton/acre & $\mathrm{Mg} \cdot \mathrm{ha}^{-1}$ & 0.4461
\end{tabular}


use in red raspberry and to develop timing and application strategies for them.

\section{Materials and methods}

Four field trials were established near Lynden, WA, in two commercial red raspberry fields (lat. $48^{\circ} 59^{\prime} \mathrm{N}$, long. $\left.122^{\circ} 22^{\prime} \mathrm{W}\right)$ with relatively uniform infestations of RLN and DN (X. bakeri). Soil in both fields was a Kickerville silt loam (Isotic, Mesic Typic Haplorthods). Trials 1, 2, and 4 were established in adjacent rows within a vigorous 'Nootka' planting, $\approx 30$ years old; Trial 3 was in a stunted and poorly growing 'Willamette' planting $\approx 35$ years old. 'Nootka' is moderately resistant to RLN, while 'Willamette' is susceptible (Bristow et al., 1980; Vrain and Daubeny, 1986). 'Nootka' plots were each 27 or $54 \mathrm{ft}$ long $\times 1$ row $(10 \mathrm{ft})$ wide and were arranged in randomized complete blocks along the rows. 'Willamette' plots were each $25 \mathrm{ft}$ long, but were otherwise similar to the 'Nootka' plots.

Ten soil cores $(1 \times 8$ inches $)$ were collected from each plot at regular increments $(\approx 3 \mathrm{ft})$ along the row and within 8 inches of plant crowns. In addition, two root cores, $6 \times 6 \times 6$ inches, were collected within 8 inches of plant crowns using a square blade shovel. Soil cores were pooled, and plant-parasitic nematodes were extracted from a $250-\mathrm{g}$ subsample by sieving-centrifugation (Jenkins, 1964). Fine roots, less than $2 \mathrm{~mm}$ in diameter, were separated from the root cores and RLN were extracted under intermittent mist (Ayoub, 1981). Nematodes were identified and counted under a stereomicroscope at $\times 40$ magnification.

Nematicides evaluated included: the soil fumigant 1,3-dichloropropene [1,3-D (Telone $^{\circledR}$ EC; Dow AgroSciences, Idianapolis, IN)], the organophosphates fenamiphos (Nemacur 3 Emulsifable Systemic; Bayer CropScience, Research Triangle Park, NC) and fosthiazate (EC 900; Syngenta Crop Protection, Greensboro, NC), and the carbamate oxamyl $\left(\right.$ Vydate $^{\circledR} \mathrm{L}$; Dupont, Wilmington, DE). A fermentation product of the fungus Myrothecium verrucaria (DiTera DF; Valent BioSciences, Libertyville, IL), was also evaluated, as was abyssinian mustard seed meal (Gies Organic Products, Moses Lake, WA). This meal is a byproduct of oil extraction from seeds. Application rates, methods, and dates for treatments in each of the four trials are listed in Table 1.

Sprayed applications were made with a carbon dioxide-powered backpack sprayer to a 4 -ft-wide band centered over the plant row. Fenamiphos, oxamyl, fosthiazate, and DiTera were applied in 43 to $46 \mathrm{gal} /$ acre spray volume, and each sprayed plot was overhead-irrigated with 0.4 inches of water immediately after treatment. DiTera was applied in $100 \mathrm{gal} / \mathrm{acre}$ spray volume. Rates for these applications were calculated as directed sprays of the full rate concentrated in the band (i.e., the rate applied was the actual amount used per acre of crop, but the product was concentrated in the 4 -ft-wide band).

Soil and root nematode population density data were $\log _{10}$ transformed to satisfy the assumptions of analysis of variance (ANOVA). ANOVA was used to determine significance of treatment effects on nematode population densities and on fruit yield. Means separations were carried out on transformed data using Fisher's protected least significant difference test (SAS version 8; SAS Institute, Cary, NC). Back-transformed data are presented in the tables.

Table 1. Treatment list for nematicide studies in red raspberry at Lynden, WA, in 2005-08 with products, rates, application methods, and application dates.

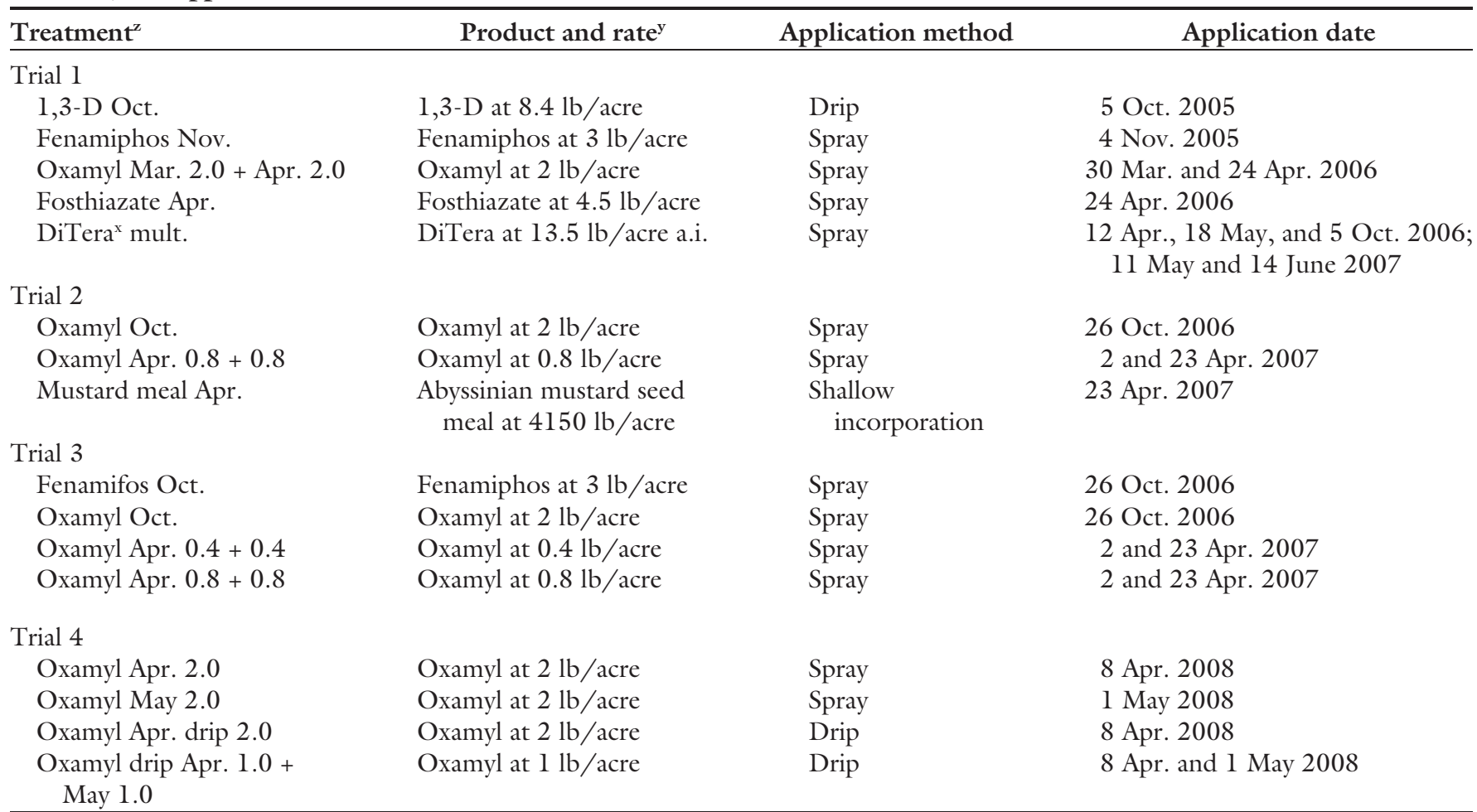

${ }^{2}$ Product and months or months of application. Spring oxamyl treatments also include rate in pounds per acre oxamyl.

${ }^{y} 1 \mathrm{lb} / \mathrm{acre}=1.1209 \mathrm{~kg} \cdot \mathrm{ha}^{-1}$.

${ }^{x}$ A fermentation product of the fungus Myrothecium verrucaria (DiTera DF; Valent BioSciences, Libertyville, IL). 
Trial I screened products for nematode suppression and effects on yield 2005 to 2008 . On 5 Oct. 2005 , plots were established and drip irrigation tapes $(0.4-\mathrm{gal} / \mathrm{h}$ emitters at 12 inch spacing) were placed on either side of the plant crowns in plots to be treated with 1,3-D. These plots were $54 \mathrm{ft}$ long to facilitate $1,3-\mathrm{D}$ treatment. All other 'Nootka' plots in this and the other trials were $27 \mathrm{ft}$ long. The tapes were pressurized with irrigation water to $15 \mathrm{psi}$, and $1,3-\mathrm{D}$ was injected into the irrigation water at $124 \mathrm{ppm}$ in $89.4 \mathrm{gal} / \mathrm{plot}$ (0.42 inch) total volume of water and product. The drip system was rinsed with an additional $15 \mathrm{gal} / \mathrm{plot}$ of water after application. Due to limited experience with postplant applications of $1,3-\mathrm{D}$ in raspberry, this low rate $(8.4$ $\mathrm{lb} /$ acre $1,3-\mathrm{D}$ ) was selected as a starting point for evaluating $1,3-\mathrm{D}$ nematicidal activity and crop safety. Soil samples were collected 5 Oct. 2005 (before fall applications). Soil and root samples were collected 30 Mar. (before spring applications), 5 July and 10 Oct. 2006, 23 Apr., 15 July, and 24 Oct. 2007, and 29 June 2008. Primocane number and height were recorded 29 Oct. 2006. Fruit was harvested mechanically (BEI International, South Haven, MI) on four representative harvest dates in 2006: 25 June, 6 July, 14 July, and 18 July. Fruit yield was not recorded on the other harvest dates for this field (typically 9 to 12 harvests at 2 - to $3-\mathrm{d}$ intervals). Fruit was similarly harvested on 3, 12, and 16 July 2007.

Trial 2 evaluated fall-applied oxamyl, spring-applied oxamyl at a reduced rate, and abyssinian mustard seed meal in 2007 to 2008 . Abyssinian mustard seed meal at $4150 \mathrm{lb} /$ acre was applied to the soil surface in a 4 - $\mathrm{ft}$ wide band over the plant row and was incorporated by covering the meal with 2 to 3 inches of soil collected from the alleyways and then overheadirrigating plots with 0.4 inch of water. Yield data were collected from machine-harvested fruit on three representative harvest dates: 3,12 , and 16 July 2007. Soil and root samples were collected on 26 Oct. 2006 (before fall treatments), and in 2007 on 28 Mar. (before spring treatments), 12 July, and 24 Oct. A final set of soil and root samples was collected 29 June 2008.

Trial 3 was conducted simultaneously with Trial 2 , but in a
'Willamette' planting. Trial 3 included the same oxamyl treatments as Trial 2, and added a further reduced-rate oxamyl treatment and fall-applied fenamiphos. Soil and root samples 2006 to 2007 and 2007 fruit yield data were collected on the same dates as for Trial 2.

Trial 4 evaluated the impacts of spring oxamyl application timing (April or May) and method (spray or drip application) on nematode suppression and yield in 2008. A single drip irrigation tape $(0.4-\mathrm{gal} / \mathrm{h}$ emitters at 12 -inch spacing) was placed along one side of the plant row next to the crowns in each plot to receive drip application. This was directly over the grower's buried drip irrigation tape. The oxamyl solution was delivered at $33.8 \mathrm{gal} /$ plot total volume of water and oxamyl; the drip irrigation system was rinsed with an additional $5 \mathrm{gal} /$ plot of water after application. Soil and root samples were collected 20 Mar. (before treatment), 28 June, and 12 Sept. 2008 on the opposite side of the crowns from the drip tapes. Fruit yield data were collected by machine harvest on three representative harvest dates: 12,18 , and 25 July.

\section{Results}

Trial 1. Oct. 2005 pretreatment RLN soil population densities [ $104.3 \pm 13.1$ nematodes per $250 \mathrm{~g}$ of soil $($ mean $\pm \mathrm{SE})]$ were not different among treatments (data not shown). DN population densities were insufficient to detect treatment effects in this trial; therefore, data for this species are not presented. There was no effect of fall treatments on Mar. 2006 RLN soil population densities (Table 2 ), but spring treatments affected root population densities on all sampling dates from July 2006 through June 2008. Treatment affected soil population densities only in samples taken from July 2006 to July 2007. Oxamyl and fosthiazate suppressed RLN in July 2006, 4 months after application; there were only 2 to 3 RLN per gram dry root in these plots, compared with 820 per gram dry root in the nontreated control. Root population densities of nematodes in oxamyl-treated plots remained lower $(P<0.05)$ than in the nontreated plots through the end of the trial in June 2008. Fosthiazate reduced RLN root population densities only in July 2006, and reduced soil population densities only in Apr. and July 2007. Nematode population densities in DiTera-, 1,3-D,- and fenamiphostreated plots were no different $(P<$ $0.05)$ than those in the nontreated control at all sampling dates. No data were collected from 1,3-D treated plots after 2006 once it was apparent that this treatment did not control RLN in soil or roots.

Primocane (first-year, vegetative cane) and floricane (second-year, flowering cane) leaves in oxamyl-treated plots were mildly chlorotic at harvest in July 2006 (data not shown). Furthermore, the yield from oxamyltreated plots was $35 \%$ lower $(P<0.05)$ than that of the nontreated control. However, primocane number and height were not different between treatments in Oct. 2006 (data not shown), and fruit yields were not different between treatments in July 2007 (Table $2, P<0.05$ ).

Trial 2. Oct. 2006 pretreatment population densities of $\mathrm{DN}$ in soil $[3.0 \pm 2.2$ per $250 \mathrm{~g}$ of soil (mean \pm $\mathrm{SE})]$ and of RLN in soil $(67.8 \pm 16.4$ per $250 \mathrm{~g}$ of soil $)$ and in roots $(811.0 \pm$ 173 per gram of dry root) did not differ among plots to be treated (data not shown). The treatment affected root and soil RLN population densities in samples taken July 2007 through June 2008, except for soil levels in Oct. 2007. Spring oxamyl applications (Oxamyl April $0.8+0.8$ ) suppressed root counts of RLN to $8 \%$ of the level of nontreated controls in July 2007 and to $28 \%$ of the level of nontreated controls in Oct. 2007, 6 months after treatment (Table 3). The spring oxamyl application also reduced July 2007 soil DN population densities to $29 \%$ of the level in nontreated plots. Fall-applied oxamyl or spring-applied abyssinian mustard seed meal reduced July 2007 RLN population densities, but not as effectively as the split spring oxamyl application did. Fall-applied oxamyl and seed meal did not suppress DN, and June 2008 DN population densities were actually higher in plots treated with fall-applied oxamyl than in nontreated control plots. Even though the spring oxamyl application rate in Trial 2 was $40 \%$ of the rate in Trial 1 , yields in Trial 2 spring oxamyl-treated plots were also numerically lower than yields in nontreated plots. However, this yield reduction was not significant in Trial 2. 
Table 2. Nematicide treatment effect on root lesion nematode population densities in roots and soil in 2006-08, and on fruit yields in 2006-07 in 'Nootka' red raspberry plots at Lynden, WA (Trial 1).

\begin{tabular}{|c|c|c|c|c|c|c|c|c|c|}
\hline \multirow[b]{3}{*}{ Treatment $^{\mathrm{z}}$} & \multicolumn{7}{|c|}{ Nematode population density } & \multirow{2}{*}{\multicolumn{2}{|c|}{$\begin{array}{c}\text { Yield } \\
\text { (tons/acre) }^{\mathrm{y}}\end{array}$}} \\
\hline & \multirow{2}{*}{$\begin{array}{l}\text { Mar. } \\
2006 \\
\end{array}$} & \multirow{2}{*}{$\begin{array}{c}\text { July } \\
2006\end{array}$} & \multirow{2}{*}{$\begin{array}{l}\text { Oct. } \\
2006\end{array}$} & \multirow{2}{*}{$\begin{array}{l}\text { Apr. } \\
2007\end{array}$} & \multirow{2}{*}{$\begin{array}{l}\text { July } \\
2007\end{array}$} & \multirow{2}{*}{$\begin{array}{c}\text { Oct. } \\
2007\end{array}$} & \multirow{2}{*}{$\begin{array}{l}\text { June } \\
2008 \\
\end{array}$} & & \\
\hline & & & & & & & & 2006 & 2007 \\
\hline Nontreated & $-^{\mathrm{w}}$ & $820{b c^{v}}^{v}$ & $1,019 \mathrm{~b}$ & $175 \mathrm{bc}$ & $1,250 \mathrm{bc}$ & $1,440 \mathrm{bc}$ & $2,163 \mathrm{~b}$ & $0.99 \mathrm{~b}$ & 1.02 \\
\hline 1,3-D Oct. & - & $1,986 \mathrm{c}$ & $651 \mathrm{~b}$ & - & - & - & - & $0.93 \mathrm{~b}$ & - \\
\hline Fenamiphos Nov. & - & $442 \mathrm{~b}$ & $483 \mathrm{~b}$ & $132 \mathrm{c}$ & $1,183 \mathrm{bc}$ & $1,597 \mathrm{c}$ & $2,734 \mathrm{~b}$ & $0.94 \mathrm{~b}$ & 0.96 \\
\hline Fosthiazate Apr. & - & $3 a$ & $314 \mathrm{~b}$ & $47 \mathrm{ab}$ & $304 \mathrm{ab}$ & $497 \mathrm{ab}$ & $2,271 \mathrm{~b}$ & $0.92 \mathrm{~b}$ & 0.96 \\
\hline DiTera $^{\mathrm{u}}$ mult. & - & $1,186 \mathrm{bc}$ & $671 \mathrm{~b}$ & $197 \mathrm{bc}$ & $1,661 \mathrm{c}$ & $1,500 \mathrm{bc}$ & $2,753 \mathrm{~b}$ & $0.95 \mathrm{~b}$ & 0.99 \\
\hline \multicolumn{10}{|c|}{ Root lesion nematodes $[\mathrm{no} . / 250 \mathrm{~g}(8.82 \mathrm{oz}) \text { soill }]^{t}$} \\
\hline Nontreated & 93 & $22 \mathrm{~b}$ & $86 \mathrm{c}$ & $68 \mathrm{~b}$ & $70 \mathrm{~b}$ & 58 & 23 & & \\
\hline 1,3-D Oct. & 103 & $34 \mathrm{~b}$ & $75 \mathrm{bc}$ & - & - & - & - & & \\
\hline
\end{tabular}

${ }^{2}$ Product and month or months of application. Spring oxamyl treatments also include rate in pounds per acre oxamyl; $1 \mathrm{lb} / \mathrm{acre}=1.1209 \mathrm{~kg} \cdot \mathrm{ha}{ }^{-1}$.

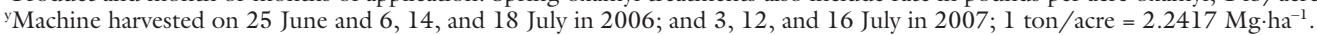

${ }^{x}$ Root lesion nematode population densities were $\log _{10}$ transformed for ANOVA and means separations; mean back-transformed numbers are presented. Italicized numbers indicate that the treatment was not applied until after this sampling date; 1 nematode $/ \mathrm{g}=28.3495$ nematodes $/ \mathrm{oz}$.

w- indicates "not determined."

${ }^{v}$ Means separation using Fisher's protected least significant difference. Numbers in a column followed by the same letter are not significantly different at $P<0.05$. Absence of letters within a column indicates that treatment effect was not significant in the ANOVA.

"A fermentation product of the fungus Myrothecium verrucaria (DiTera DF; Valent BioSciences, Libertyville, IL).

${ }^{\mathrm{t}} \mathrm{l}$ nematode per $250 \mathrm{~g}=0.1134$ nematode $/ \mathrm{oz}$.

Table 3. Nematicide treatment suppression of root lesion and dagger nematode population densities in 2007-08, and 2007 fruit yields in 'Nootka' red raspberry plots at Lynden, WA (Trial 2).

\begin{tabular}{|c|c|c|c|c|c|}
\hline \multirow[b]{2}{*}{ Treatment $^{\mathrm{z}}$} & \multicolumn{4}{|c|}{ Nematode population density } & \multirow{2}{*}{$\frac{\text { Yield (tons } / \text { acre })^{\mathrm{y}}}{2007}$} \\
\hline & Mar. 2007 & July 2007 & Oct. 2007 & June 2008 & \\
\hline \multicolumn{6}{|c|}{ Root lesion nematodes (no./g dry root) $)^{x}$} \\
\hline Oxamyl Oct. & 582 & $348 \mathrm{~b}$ & $1,376 \mathrm{~b}$ & $3,746 \mathrm{~b}$ & 0.99 \\
\hline Oxamyl Apr. $0.8+0.8$ & 701 & 96 a & $410 \mathrm{a}$ & $1,220 \mathrm{a}$ & 0.80 \\
\hline Mustard meal Apr. & 307 & $377 \mathrm{~b}$ & $1,280 \mathrm{~b}$ & $3,302 \mathrm{~b}$ & 0.92 \\
\hline Nontreated & 68 & $17 \mathrm{a}$ & 57 & $23 \mathrm{a}$ & \\
\hline Oxamyl Oct. & 62 & $36 \mathrm{~b}$ & 58 & $46 \mathrm{ab}$ & \\
\hline Oxamyl Apr. $0.8+0.8$ & 79 & $8 \mathrm{a}$ & 13 & $23 \mathrm{a}$ & \\
\hline Mustard meal Apr. & 72 & $33 \mathrm{ab}$ & 49 & $78 \mathrm{~b}$ & \\
\hline \multicolumn{6}{|c|}{ Dagger nematodes (no. $/ 250 \mathrm{~g}$ soil) } \\
\hline Nontreated & 4 & $62 \mathrm{~b}$ & $28 \mathrm{ab}$ & $25 \mathrm{ab}$ & \\
\hline
\end{tabular}

${ }^{2}$ Product and month or months of application. Spring oxamyl treatments also include rate in pounds per acre oxamyl; $1 \mathrm{lb} / \mathrm{acre}=1.1209 \mathrm{~kg} \cdot \mathrm{ha}{ }^{-1}$.

${ }^{y}$ Machine harvested on 3, 12, and 16 July 2007; l ton/acre $=2.2417 \mathrm{Mg} \cdot \mathrm{ha}^{-1}$.

${ }^{x}$ Nematode population densities were $\log _{10}$ transformed for ANOVA and means separations; mean back-transformed numbers are presented. Italicized numbers indicate that the treatment was not applied until after this sampling date; 1 nematode $/ \mathrm{g}=28.3495$ nematodes/oz.

${ }^{w}$ Means separation using Fisher's protected least significant difference. Numbers in a column followed by the same letter are not significantly different at $P<0.05$. Absence of letters within a column indicates that treatment effect was not significant in the ANOVA.

'l nematode per $250 \mathrm{~g}=0.1134$ nematode $/ \mathrm{oz}$.

Trial 3. Oct. 2006 pretreatment RLN population densities were not different among plots and averaged $1505 \pm 528$ per gram of dry weight of roots and $201 \pm 75$ per $250 \mathrm{~g}$ of soil. Pretreatment DN population densities $(1.2 \pm 1.3$ per $250 \mathrm{~g}$ of soil) were very low, and remained so throughout the trial with no differences noted for this nematode (data not shown). Treatments consistently affected root RLN population densities in Mar. 
through Oct. 2007 samples, but only affected soil population densities in the July 2007 sample (Table 4). Spring applications of oxamyl (Oxamyl Apr. $0.4+0.4$ or Oxamyl Apr. $0.8+0.8$ ) reduced RLN root and soil population densities in July, but only the higher rate remained effective in October. Fall applications of fenamiphos and oxamyl had no effect on root and soil RLN population densities. In contrast with the reaction of 'Nootka' in Trials 1 and 2 , oxamyl was not phytotoxic to 'Willamette' in Trial 3 , and fruit yield was unaffected by any of the oxamyl treatments (Table 4).

Trial 4. Mar. 2008 pretreatment densities of DN in soil and of RLN in soil and roots did not differ among plots to be treated (Table 5). Treatment affected soil and root RLN population densities in July. By September, treatment affected root RLN population densities only. Likewise, treatment affected DN soil population densities in July but not in September. April and May spray-applied oxamyl treatments effectively reduced root RLN numbers through the season, but drip-applied oxamyl at the same rate $(2.0 \mathrm{lb} / \mathrm{acre})$ did not. The May spray applications also reduced soil population densities of $\mathrm{DN}$ in July, 3 months after treatment. As in Trials 1 and 2 , all of the springapplied oxamyl treatments reduced 'Nootka' fruit yields relative to those of the nontreated control.

\section{Discussion}

Spring spray applications of oxamyl or fosthiazate suppressed RLN root population densities in each of the four trials in this study. Fall oxamyl applications were ineffective. Spring applications precede a flush of raspberry root growth (Atkinson, 1973). If this flush is protected, raspberry root growth may outpace nematode reproduction, and nematode population densities may remain low. Pinkerton et al. (1988) showed that spring applications of oxamyl to peppermint (Mentha xpiperita) controlled RLN, but fall applications were ineffective. In that study, new peppermint roots in spring-treated plots grew well with reduced nematode parasitism, such that RLN population densities in the roots remained low through June, but increased by the end of August. Nematode population densities were lower and peppermint yield was higher for 2 years after the spring treatments. Oxamyl applied just before root growth controlled RLN in other crops, including potato [Solanum tuberosum (Olthof et al., 1985)] and alfalfa [Medicago sativa (Townshend and Chiba, 1987)]. In the present study, springapplied fosthiazate reduced July root RLN population densities, but no longer suppressed RLN by October. Because fosthiazate is not systemic, incomplete coverage of the root system may have left RLN in parts of the roots unaffected; these survivors could then have colonized the new roots.

Oxamyl also suppressed one DN, $X$. bakeri, in agreement with earlier reports. (Forer et al., 1975; McElroy, 1975). These results are promising because other postplant management techniques for DN in raspberry are ineffective (Lolas et al., 1993; McElroy, 1991). Spring oxamyl treatments reduced $X$. bakeri numbers, but did not eliminate it. If these results apply to $X$. americanum, oxamyl applications might not prevent the spread of ToRSV, which is vectored by $X$. americanum in raspberry at very low nematode population densities (Pinkerton et al., 2008).

The rate of spring-applied oxamyl determined the duration of nematode suppression. Oxamyl applied twice in the spring at $2 \mathrm{lb} /$ acre in Trial $\mathrm{l}$ suppressed RLN root population densities for 2 years (Table 2). Oxamyl applied twice in the spring at $0.8 \mathrm{lb} /$ acre in Trials 2 and 3 suppressed root RLN population densities through the following October, but RLN numbers rebounded more rapidly following applications at $0.4 \mathrm{lb} /$ acre in Trial 3 (Tables 3 and 4). Oxamyl has a short half-life in soil and in plants (Harvey and Han, 1978; Wright et al., 1980), thus the long-term effect on nematode population densities is probably not due to continued direct toxicity. Furthermore, oxamyl is nematistatic;

Table 4. Nematicide treatment suppression of 2007 root lesion nematode population densities and fruit yields in 'Willamette' red raspberry plots at Lynden, WA (Trial 3).

\begin{tabular}{|c|c|c|c|c|}
\hline \multirow[b]{2}{*}{ Treatment $^{\mathrm{z}}$} & \multicolumn{3}{|c|}{ Nematode population density } & \multirow{2}{*}{$\frac{\text { Yield (tons/acre) }}{2007}$} \\
\hline & Mar. 2007 & July 2007 & Oct. 2007 & \\
\hline \multicolumn{5}{|c|}{ Root lesion nematodes (no./g dry root) ${ }^{x}$} \\
\hline Fenamifos Oct. & $921 \mathrm{~b}$ & $2,231 \mathrm{c}$ & $1,890 \mathrm{~b}$ & 0.89 \\
\hline Oxamyl Oct. & $1007 \mathrm{~b}$ & $1,310 \mathrm{c}$ & $1,408 \mathrm{~b}$ & 1.00 \\
\hline Oxamyl Apr. $0.4+0.4$ & $64,1 a b$ & $293 \mathrm{~b}$ & $715 \mathrm{~b}$ & 0.82 \\
\hline Nontreated & 105 & $202 \mathrm{c}$ & 107 & \\
\hline Fenamifos Oct. & 88 & $187 \mathrm{c}$ & 180 & \\
\hline Oxamyl Oct. & 120 & $107 \mathrm{bc}$ & 45 & \\
\hline Oxamyl Apr. $0.4+0.4$ & 87 & $79 \mathrm{ab}$ & 64 & \\
\hline Oxamyl Apr. $0.8+0.8$ & 85 & $54 \mathrm{a}$ & 42 & \\
\hline
\end{tabular}

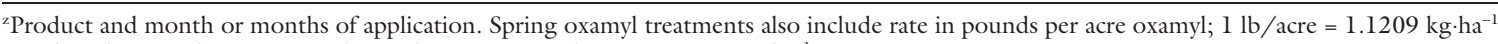

${ }^{y}$ Machine harvested on 3, 12, and 16 July 2007; l ton/acre $=2.2417 \mathrm{Mg} \cdot \mathrm{ha}^{-1}$

${ }^{x}$ Root lesion nematode population densities were $\log _{10}$ transformed for ANOVA and means separations; mean back-transformed numbers are presented. Italicized numbers indicate that the treatment was not applied until after this sampling date; 1 nematode $/ \mathrm{g}=28.3495$ nematodes $/ \mathrm{oz}$.

"Means separation using Fisher's protected least significant difference. Numbers in a column followed by the same letter are not significantly different at $P<0.05$. Absence of letters within a column indicates that treatment effect was not significant in the ANOVA.

${ }^{v} 1$ nematode per $250 \mathrm{~g}=0.1134$ nematode $/ \mathrm{oz}$. 
Table 5. Nematicide treatment suppression of 2008 root lesion nematode population densities and fruit yields in 'Nootka' red raspberry plots at Lynden, WA (Trial 4).

\begin{tabular}{|c|c|c|c|c|}
\hline \multirow[b]{2}{*}{ Treatment $^{\mathrm{z}}$} & \multicolumn{3}{|c|}{ Nematode population density } & \multirow{2}{*}{$\frac{\text { Yield (tons } / \text { acre) }}{2008}$} \\
\hline & Mar. 2008 & July 2008 & Sept. 2008 & \\
\hline \multicolumn{5}{|c|}{ Root lesion nematodes (no./g dry root) ${ }^{x}$} \\
\hline Oxamyl Apr. 2.0 & 484 & $127 \mathrm{a}$ & $97 \mathrm{a}$ & $0.69 \mathrm{~b}$ \\
\hline Oxamyl May 2.0 & 790 & $137 \mathrm{a}$ & $125 \mathrm{a}$ & $0.57 \mathrm{~b}$ \\
\hline Oxamyl Apr. drip 2.0 & 559 & $3,106 \mathrm{~d}$ & $1,168 \mathrm{~b}$ & $0.74 \mathrm{~b}$ \\
\hline Nontreated & 42 & $61 b^{x}$ & 59 & \\
\hline Oxamyl Apr. 2.0 & 77 & $24 \mathrm{~b}$ & 14 & \\
\hline Oxamyl May 2.0 & 67 & $6 a$ & 18 & \\
\hline Oxamyl Apr. drip 2.0 & 63 & $66 \mathrm{~b}$ & 13 & \\
\hline Oxamyl drip Apr. $1.0+$ May 1.0 & 34 & $53 \mathrm{~b}$ & 44 & \\
\hline Oxamyl May 2.0 & 4 & $17 \mathrm{a}$ & 12 & \\
\hline Oxamyl Apr. drip 2.0 & 40 & $71 \mathrm{~b}$ & 15 & \\
\hline Oxamyl drip Apr. $1.0+$ May 1.0 & 19 & $39 \mathrm{ab}$ & 10 & \\
\hline
\end{tabular}

${ }^{2}$ Product and month or months of application. Spring oxamyl treatments also include rate in pounds per acre oxamyl; $1 \mathrm{lb} / \mathrm{acre}=1.1209 \mathrm{~kg} \cdot \mathrm{ha}{ }^{-1}$.

${ }^{y}$ Machine harvested on 12,18 , and 25 July $2008 ; 1$ ton/acre $=2.2417 \mathrm{Mg} \cdot \mathrm{ha}^{-1}$.

${ }^{x}$ Nematode population densities were $\log _{10}$ transformed for ANOVA and means separations; mean back-transformed numbers are presented. Italicized numbers indicate that the treatment was not applied until after this sampling date; 1 nematode $/ \mathrm{g}=28.3495$.

"Means separation using Fisher's protected least significant difference. Numbers in a column followed by the same letter are not significantly different at $P<0.05$. Absence of letters within a column indicates that treatment effect was not significant in the ANOVA.

vl nematode per $250 \mathrm{~g}=0.1134$ nematode/oz.

nematodes can regain activity once the oxamyl concentration declines (McGarvey et al., 1984; Wright et al., 1980). We examined root core samples collected in 2007 and observed more fine roots on spring oxamyltreated plants than on plants that received other treatments (data not shown). Enhanced root proliferation in the Spring 2006 oxamyl-treated plots may have allowed many roots to escape nematode infestation, resulting in lower root RLN population densities for 2 years following treatment.

Spring applications of oxamyl consistently reduced yields of 'Nootka', but not of 'Willamette' in this study. No yield reduction was noted following fall applications. Reduced yields have not been observed in similar studies with 'Meeker', the most commonly grown variety in Washington, Oregon, and British Columbia (J. De Francesco, personal communication). Data are needed on the response of different raspberry genotypes and cultivars to spring applications of oxamyl.

Although spring oxamyl and fosthiazate applications reduced RLN and DN population densities, these treatments did not increase yields in infested plantings of 'Nootka' or 'Willamette'. However, we monitored plant yields for only 1 or 2 years after treatment, and yield increases resulting from nematicide treatments may not be evident until several years following treatment for RLN (McElroy, 1991). The delay in yield response may result from the need for the plant to re-develop a healthy root system before cane growth and fruit development can improve.

Other treatments did not suppress RLN well. Fall applications of fenamiphos in Trial 1 and Trial 3 did not reduce RLN populations in roots or soil, even though this treatment was effective in greenhouse trials on strawberry [Fragaria $\times$ ananassa (Pinkerton and Kitner, 2006)], and in field trials on red raspberry (Lolas et al., 1993). Fall application of fenamiphos to raspberry was recommended and used for years (McElroy, 1992). However, fenamiphos could not be applied less than 6 months before harvest, precluding spring application in most circumstances (McElroy, 1991). Abyssinian mustard seed meal apparently provided modest, short-term nematode suppression, although relatively low pretreatment root RLN population densities in these plots cast some doubt upon this observation (Table $3)$. Because the meal was applied to the surface and then covered with soil, it may not have liberated nematicidal compounds throughout the root zone. The difficulty of incorporating seed meal in established raspberry hills without damaging raspberry roots limits the utility of mustard seed meals in commercial raspberry production. DiTera and 1,3-D did not affect root or soil nematode densities, although higher rates of 1,3-D (broadcast applications of up to $345 \mathrm{lb} /$ acre) have long been used to eliminate nematodes before planting (McElroy, 1991). The 1,3-D application in this study was probably ineffective because of the low rate used $(8.4 \mathrm{lb} /$ acre $)$, but inadequate distribution throughout the root zone by the drip system may also have been a factor.

Vrain and Keng (1986) reported significant suppression of RLN population densities and increased fruit yields following drip application of fenamiphos, but we did not observe similar results with drip-applied oxamyl. Oxamyl drip applications in Trial 4 were ineffective, even though simultaneous spray applications controlled RLN and DN. Oxamyl was applied with drip tape placed just to the west of the plant crowns, and soil and root samples were collected to 
the east of the crowns. Although the water volume for the drip application (38.8 $\mathrm{gal} / \mathrm{plot})$ was comparable to the volume used to incorporate the spray-applied treatments $(0.4$ inches, $42 \mathrm{gal} / \mathrm{plot})$, the water and oxamyl may not have been as evenly distributed across the root zone in the drip applications.

Soil RLN population densities generally followed patterns similar to root data, but population densities were always much higher in roots than in soil (Tables 2-5). Treatment significantly affected root RLN population densities on each of the 14 sampling dates in Trials 1 through 4, but only affected soil population densities on 8 of the 14 dates (Tables 2$5)$. Because RLN feeds only in cortical tissue of roots, nematode population densities in the root are a better indicator of the impact of nematode parasitism on plant health than are densities in the soil. When possible, RLN management decisions should be based upon root rather than soil population densities.

Root RLN population densities in nontreated plots were consistently highest in the summer and fall, and were lowest in the spring (Tables 2-5). These dynamics follow raspberry root growth, which is greatest May through September and is closely correlated with soil temperature (Atkinson, 1973). Lolas et al. (1993) observed similar seasonal RLN population dynamics in Oregon raspberry fields. Vrain et al. (1997) and Forge et al. (1998) reported that RLN population dynamics were inconsistent from year to year, but that nematode population densities in fine roots were highest in the late summer and fall.

Spring sprayed applications of $0.8-4.0 \mathrm{lb} /$ acre oxamyl suppressed RLN and DN population densities. The duration of suppression depended upon the rate used; a rate of $1.6 \mathrm{lb} /$ acre oxamyl suppressed plant-parasitic population densities for at least 1 year. These treatments suppressed yields of 'Nootka' but not of 'Willamette'. Oxamyl shows promise as a muchneeded postplant treatment for nematode management in red raspberry.

\section{Literature cited}

Atkinson, D. 1973. Seasonal changes in the length of white unsuberized root on raspberry plants grown under irrigated conditions. J. Hort. Sci. Biotechnol. 48:413-419.

Ayoub, S.M. 1981. Plant Nematology. An agricultural training aid. NemaAid Publications, Sacramento, CA.

Belair, G. 1991. Effect of preplant soil fumigation on nematode population densities and on growth and yield of raspberry. Phytoprotection 72:21-25.

Bristow, P.R., B.H. Barritt, and F.D. McElroy. 1980. Reaction of red raspberry clones to root lesion nematode. Acta Hort. 112:39-43.

Forer, L.B., D.L. Trudgill, and T.J.W. Alphey. 1975. Some effects of oxamyl on the virus-vector nematodes Longidorus elongatus and Xiphinema diversicaudatum. Ann. Appl. Biol. 81:207-214.

Forge, T.A., R. DeYoung, and T.C. Vrain. 1998. Temporal changes in the vertical distribution of Pratylenchus penetrans under raspberry. J. Nematol. 30:179-183.

Harvey, J. and J.C.Y. Han. 1978. Decomposition of oxamyl in soil and water. J. Agr. Food Chem. 26:536-541.

Jenkins, W.R. 1964. A rapid centrifugalflotation technique for separating nematodes from soil. Plant Dis. Rptr. 48:692.

Lolas, M.A., K.J. Merrifield, J.N. Pinkerton, and R.E. Ingham. 1993. Effect of fenamiphos on population dynamics of Pratylenchus penetrans and Xiphinema americana in Oregon red raspberry fields. J. Nematol. 24:605.

McElroy, F.D. 1972. Studies on the host range of Xiphinema bakeri and its pathogencity to raspberry. J. Nematol. 4:16-22.

McElroy, F.D. 1975. Nematode control in established red raspberry plantings, p. 445446. In: F. Lamberti, C.E. Taylor, and J.W. Seinhorst (eds.). Nematode vectors of plant viruses. Plenum Press, New York.

McElroy, F.D. 1991. Nematode parasites, p. 59-62. In: M.A. Ellis, R.H. Converse, R.N. Williams, and B. Williamson (eds.). Compendium of raspberry and blackberry diseases and pests. APS Press, St. Paul, $\mathrm{MN}$.

McElroy, F.D. 1992. A plant health care program for brambles in the Pacific Northwest. J. Nematol. 24:457-462.

McGarvey, B.D., J.W. Potter, and M. Chiba. 1984. Nematostatic activity of oxamyl and N,N-dimethyl-cyanoformamide (DMCF) on Meloidogyne incognita juveniles. J. Nematol. 16:328-332.

Olthof, T.H.A., B.D. McGarvey, and M. Chiba. 1985. Oxamyl in the control of Pratylenchus penetrans on potatoes. Can. J. Plant Pathol. 7:155-160.
Pinkerton, J.N. and M.L.C. Kitner. 2006. Effects of biologically derived products on mobility and reproduction of the root lesion nematode, Pratylenchus penetrans, on strawberry. Nematropica 36:176-190.

Pinkerton, J.N., H.J. Jensen, G.B. Newcomb, and R.E. Ingham. 1988. Management of Pratylenchus penetrans damage to peppermint with selected nematicides. Plant Dis. 72:167-170.

Pinkerton, J.N., J. Kraus, R.R. Martin, and R.P. Schreiner. 2008. Epidemiology of Xiphinema americanum and tomato ringspot virus on red raspberry, Rubus idaeus. Plant Dis. 92:364-371.

Szczygiel, A. and Z. Rebandel. 1988. Control of replanting problem in raspberry. Acta Hort. 233:81-84.

Townshend, J.L. and M. Chiba. 1987. Control of Pratylenchus penetrans and Meloidogyne hapla and yield response of alfalfa due to oxamyl seed treatments. J. Nematol. 19:454-458.

Trudgill, D.L. 1986. Effects of soil treatment for the control of Pratylenchus penetrans (Nematoda) on the growth and yield of raspberry ( $R$ ubus ideaus) in eastern Scotland. Crop Res. 26:89-109.

U.S. Environmental Protection Agency. 2008. Implementation of risk mitigation measures for soil fumigant pesticides. 1 Apr. 2009. <http://www.epa.gov/opp00001/ reregistration/soil_fumigants $/>$.

Vrain, T.C. and H.A. Daubeny. 1986. Relative resistance of red raspberry and related genotypes to the root lesion nematode. HortScience 21:1435-1437.

Vrain, T.C. and H.S. Pepin. 1989. Effect of Pratylenchus penetrans on root rot of red raspberry caused by Phytophthora erythroseptica. Acta Hort. 262:231-240.

Vrain, T.C. and J.C.W. Keng. 1986. Application of nonvolatile nematicides through a trickle irrigation system to control Pratylenchus penetrans in raspberries. Can. J. Plant Pathol. 8:97-101.

Vrain, T.C. and R.J. Copeman. 1987. Interactions between Agrobacterium tumefaciens and Pratylenchus penetrans in the roots of two red raspberry cultivars. Can. J. Plant Pathol. 9:236-240.

Vrain, T.C., T.A. Forge, and R. DeYoung. 1997. Population dynamics of Pratylenchus penetrans parasitizing raspberry. Fundam. Appl. Nematol. 20:29-36.

Wright, D.J., A.R.K. Blyth, and P.E. Pearson. 1980. Behaviour of the systemic nematicide oxamyl in plants in relation to control of invasion and development of Meloidogyne incognita. Ann. Appl. Biol. 96:323-334. 